\title{
KADAR SERUM GLUTAMIC OXALOACETAT TRANSAMINASE DAN SERUM GLUTAMIC PYRUVIC TRANSAMINASE PADA PASIEN TUBERKULOSIS PARU SELAMA DUA BULAN BERJALANNYA PEMBERIAN OBAT ANTI TUBERKULOSIS KOMBINASI DOSIS TETAP
}

\author{
${ }^{1}$ Ayu R. Pribadini Nelwan \\ 2Stella Palar \\ ${ }^{2}$ Julia. C. M. Lombo
${ }^{1}$ Kandidat Skripsi Fakultas Kedokteran Universitas Sam Ratulangi Manado
${ }^{2}$ Bagian Ilmu Penyakit Dalam Universitas Sam Ratulangi Manado
Email: dinismart10@yahoo.com

\begin{abstract}
Tuberculosis (TB) is still a health problem around the world. According to statistics of the World Health Organization (WHO) showed that Indonesia's ranking were down from third to fifth in the world. However there are also challenges in the treatment of tuberculosis worldwide and in Indonesia, like treatment failure, dropping out of treatment, and inappropriate treatment. This study aimed to compare the serum levels of SGOT (AST) and SGPT (ALT) in patients with pulmonary TB during two months administration of OAT KDT. This study was a cross sectional analytic study using secondary data and blood sample from patients with pulmonary TB. The samples in this study was patients with pulmonary tuberculosis, pulmonary tuberculosis first category, pulmonary tuberculosis BTA smear $(+)$, pulmonary tuberculosis with controlled hypertension, pulmonary tuberculosis suspected MDR, pulmonary tuberculosis with secondary infections, pulmonary tuberculosis on treatment, and pulmonary tuberculosis which dropping put of treatment. The analysis of data changes on SGOT levels before and after administration of Anti-Tuberculosis Drugs (OAT) shows that the value of $\mathrm{z}_{\text {count }}: 2,223>\mathrm{z}_{\text {table }}: 1,645$ with a significance value of $\mathrm{p}=0,026<0,05$. This indicates that there is an effect of the Anti Tuberculosis Drugs (OAT) fixed-dose combination toward SGOT levels. The analysis of data changes on SGPT levels before and after administration of Anti-Tuberculosis Drugs (OAT) shows that the value of $\mathrm{z}_{\text {count }}$ : $2,045>\mathrm{z}_{\text {table }}$ : 1,645 with a significance value of $\mathrm{p}=0,041<0,05$. This indicates that there is an effect of the Anti Tuberculosis Drugs (OAT) fixed-dose combination toward SGPT levels. There are a significant correlation between serum levels of glutamic oxaloacetat transaminase and glutamic pyruvic transaminase in patients with pulmonary tuberculosis during two months administration of anti-tuberculosis medication with a fixed-dose combination and an increasing levels of SGOT and SGPT in pulmonary tuberculosis patients.
\end{abstract}

\begin{abstract}
Abstrak: Penyakit Tuberkulosis (TB) masih merupakan masalah kesehatan di dunia. Menurut data statistik World Health Organization (WHO) menunjukkan Indonesia turun dari peringkat tiga menjadi peringkat kelima dunia. Namun masih terdapat pula tantangan dalam pengobatan TB di dunia dan Indonesia, antara lain kegagalan pengobatan, putus pengobatan, dan pengobatan yang tidak tepat. Penelitian ini ditujukan untuk mengetahui perbandingan kadar serum SGOT dan SGPT pada pasien TB Paru selama dua bulan pemberian OAT KDT. Penelitian ini merupakan penelitian analitik cross sectional dengan menggunakan data sekunder dan pengambilan sampel darah pada pasien TB Paru. Pada penelitian ini sampel yang digunakan adalah penderita TB Paru, TB Paru kategori 1, TB paru BTA (+), TB Paru dengan Hipertensi terkontrol, TB paru suspek MDR, TB Paru dengan infeksi sekunder, TB paru on treatment, dan TB paru putus obat. Hasil analisis data perubahan kadar SGOT sebelum dan setelah diberikan Obat Anti Tuberkulosis menunjukkan bahwa nilai $\mathrm{z}_{\text {hitung }}: 2,223$ $>\mathrm{z}_{\text {tabel }}: 1,645$ dengan nilai signifikansi $\mathrm{p}=0,026<0,05$. Hal ini menunjukkan bahwa terdapat pengaruh pemberian Obat Anti Tuberkulosis (OAT) kombinasi dosis tetap terhadap kadar SGOT. Hasil analisis data perubahan kadar SGPT sebelum dan setelah diberikan Obat Anti Tuberkulosis menunjukkan bahwa nilai $\mathrm{z}_{\text {hitung: }}$ : $2,045>\mathrm{z}_{\text {tabel }}: 1,645$ dengan nilai signifikansi $\mathrm{p}=0,041<0,05$. Hal ini menunjukkan bahwa terdapat pengaruh pemberian Obat Anti Tuberkulosis (OAT) kombinasi dosis tetap terhadap kadar SGPT. Terdapat hubungan yang signifikan antara kadar serum glutamic oxaloacetic transaminase dan serum glutamic pyruvic transaminase pada pasien tuberkulosis paru selama dua bulan berjalannya pemberian obat anti tuberkulosis kombinasi dosis tetap dan terdapat peningkatan kadar SGOT dan SGPT pada pasien tuberkulosis paru.
\end{abstract}


Tuberkulosis paru termasuk suatu pneumonia, yaitu pnemonia yang disebabkan oleh M.tuberculosis. Tuberkulosis paru mencakup 80\% dari keseluruhan kejadian penyakit tuberkulosis, sedangkan 20\% selebihnya merupakan tuberkulosis ekstrapulmona Diperkirakan bahwa sepertiga penduduk dunia pernah terinfeksi kuman M.Tuberkulosis ${ }^{1}$

Menurut Departemen Kesehatan, kini penanggulangan TB di Indonesia menjadi lebih baik, data statistik World Health Organization (WHO) menunjukkan Indonesia turun dari peringkat tiga menjadi peringkat ke lima dunia dengan jumlah insiden terbanyak TB pada tahun 2009 setelah India, China, Afrika Selatan, dan Nigeria. Beberapa hasil dan pencapaian program TB, menurut Tjandra Yoga angka keberhasilan pengobatan TB di Indonesia naik sebesar 91\% pada tahun 2008. Target pencapaian angka penemuan kasus TB Paru Case Detection Rate (CDR) tahun 2009 sudah mencapai 73,1\%. Insiden TB Paru sejaktahun 1998 sampai tahun 2005 trennya menurun dan rata-rata penurunan insiden TB Paru positif tahun 2005-2007 adalah 2,4\%. ${ }^{3}$

Directly observed treatment short course dilaksanakan untuk mengatasi tingginya angka kesakitan TB. Paduan obat antituberkulosis (OAT) yang dilaksanakan dengan strategi DOTS ini mempunyai efektiviti yang tinggi dalam pengobatan TB paru tetapi angka kesembuhan yang di hasilkan masih rendah. Ketidakberhasilan tersebut diduga akibat kepatuhan yang rendah untuk berobat secara teratur oleh karena itu dibuat sediaan obat baru yang berisi 2 atau lebih OAT yang di sebut dengan kombinasi dosis tetap (KDT). Penggunaan KDT dapat menurunkan risiko penggunaan obat tunggal yang salah sehingga menyebabkan timbulnya multiple drug resistant tuberculosis (MDR TB). ${ }^{2}$

Penelitian ini di lakukan untuk mengetahui Kadar Serum Glutamic Oxaloacetic-Transaminase (SGOT) dan Serum Glutamac-piruvat Transaminase (SGPT) Pada Pasien Tuberkulosis Paru Setelah Dua Bulan Pemberian Obat Anti Tuberkulosis dengan Kadar Dosis Tetap. Rumusan masalah pada penelitiian ini yaitu
Apakah ada perbedaan antara Kadar Serum Glutamic Oxaloacetat-Transaminase (SGOT) dan Serum Glutamic-pyruvic Transaminase (SGPT) Pada Pasien Tuberkulosis Paru Setelah Dua Bulan Pemberian Obat Anti Tuberkulosis Kombinasi Dosis Tetap. Dengan adanya penelitian ini maka diharapkan dapat mengetahui Kadar Serum Glutamic Oxaloacetat-Transaminase (SGOT) dan Serum Glutamic-pyruvic Transaminase (SGPT) Pada Pasien Tuberkulosis Paru Setelah Dua Bulan Pemberian Obat Anti Tuberkulosis Kombinasi Dosis Tetap.

\section{METODE PENELITIAN}

Desain penelitian ini berupa Analitik Cross sectional yang dilakukan pada bulan Oktober 2012-Desember 2012 di Poliklinik Paru di BLU RSUP Prof. Dr.R.D. Kandou Manado. Populasi dan Sampel penelitian adalah Pasien dengan Diagnosis TB Paru di poliklinik Paru di Bagian/SMF Ilmu Penyakit Dalam FK Unsrat/BLU RSUP Prof Dr. R. D. Kandou Manado. Kriteria inklusi antara lain: (1) TB Paru yang sudah 2 bulan di beri OAT KDT, (2) TB Paru dengan Hepatotoksik sedangkan kriteria eksklusi adalah TB Paru yang menolak penelitian.

Variabel Penelitian terdiri atas dua yaitu variabel bebas diantaranya: (1) OAT KDT ( Obat Anti Tuberkulosis Kombinasi Dosis Tetap), (2) Umur, (3) Jenis Kelamin. Variabel terikat berupa kadar SGOT dan SGPT.

Instrumen penelitian antara lain: (1) Catatan Rekam Medik pasien TB Paru di Poliklinik Paru di Bagian Ilmu Penyakit Dalam FK Unsrat/BLU RSUP Prof Dr. R. D. Kandou Manado (2) Alat tulis menulis, (3) Komputer. Data dikumpulkan dengan melihat catatan rekam medik pasien TB Paru yang datang berobat di Poliklinik Paru Bagian/SMF Ilmu Penyakit Dalam FK Unsrat/BLU RSU Prof. Dr. R. D. Kandou Manado, kemudain diolah dengan komputer dan disajikan dalam bentuk tulisan dan Tabel.

\section{HASIL PENELITIAN}

Hasil penelitian ini menggunakan analisis statistik dengan menggunakan 
Wilcoxon Sign Rank Test sebagai uji alternatif Pairing $t$ Test dimana sebaran data tidak memenuhi asumsi normalitas dan di dapatkan bahwa ada hubungan antara Obat Anti Tuberkulosis Kombinasi Dosis tetap (OAT KDT) seperti Rifamficin dan Isoniazid yang mempunyai efek hepatotoksik sehingga terjadi peningkatan Kadar SGOT dan SGPT. Hal ini sesuai dengan penelitian yang di lakukan oleh julita $\mathrm{N}$ yang menunjukan bahwa obat yang di resepkan (termasuk asetaminofen) menyebabkan $>50 \%$ kasus gagal hati akut. Saat ini efek hepatotoksik merupakan alasan utama terhentinya pengembangan obat lebih lanjut dan di tariknya obat yang telah di setujui oleh FDA dari pasaran (Andrade, et al, 2007). Salah satu alasan penarikan obat di pasaran adalah karena obat-obat tersebut menyebabkan peningkatan kadar enzimenzim di hati. ${ }^{4}$

\section{Karakteristik sampel}

Sampel pada penelitian ini yaitu pasien dengan diagnosis TB Paru, TB Paru kategori 1, TB paru BTA $(+)$, TB Paru dengan Hipertensi terkontrol, TB paru suspect MDR, TB Paru dengan Infeksi sekunder, TB paru On treatmen, dan TB Paru putus obat di bagian C5 dan Poliklinik Paru di BLU RSUP Prof. Dr.R.D. Kandou Manado.

Tabel 1. Distribusi Kadar SGOT berdasarkan Jenis Kelamin

\begin{tabular}{lccc}
\hline & \multicolumn{2}{c}{ SGOT dan SGPT } & Jumlah \\
\cline { 2 - 3 } Jenis kelamin & Meningkat & Menurun & $\%$ \\
\hline Perempuan & $45 \%$ & $10 \%$ & $55 \%$ \\
Laki-laki & $45 \%$ & $0 \%$ & $45 \%$ \\
Total & $55 \%$ & $45 \%$ & $100 \%$ \\
\hline
\end{tabular}

Tabel 2. Distribusi Kadar SGPT berdasarkan Jenis kelamin

\begin{tabular}{lccc}
\hline \multirow{2}{*}{ Berat Badan } & \multicolumn{2}{c}{ SGOT dan SGPT } & Jumlah \\
\cline { 2 - 3 } & Meningkat & Menurun & $\%$ \\
\hline $36-45 \mathrm{~kg}$ & $36 \%$ & $9 \%$ & $45 \%$ \\
$46-55 \mathrm{~kg}$ & $9 \%$ & $0 \%$ & $9 \%$ \\
$56-65 \mathrm{~kg}$ & $46 \%$ & $0 \%$ & 46 \\
Total & $91 \%$ & $9 \%$ & $100 \%$ \\
\hline
\end{tabular}

Tabel 3. Distribusi Kadar SGOT dan SGPT berdasarkan Usia

\begin{tabular}{lccc}
\hline \multirow{2}{*}{ Usia } & \multicolumn{2}{c}{ SGOT dan SGPT } & \multirow{2}{*}{$\begin{array}{c}\text { Jumlah } \\
\text { \%on }\end{array}$} \\
\cline { 2 - 3 } & Meningkat & Menurun & \\
\hline 15-30thn & $46 \%$ & $9 \%$ & $55 \%$ \\
31-50thn & $27 \%$ & $0 \%$ & $27 \%$ \\
51-70thn & $18 \%$ & $0 \%$ & $18 \%$ \\
Total & $91 \%$ & $9 \%$ & $100 \%$ \\
\hline
\end{tabular}

Tabel 4. Distribusi kadar SGOT dan kadar SGPT Berdasarkan Pemeriksaan Laboratorium

\begin{tabular}{lccc}
\hline Pemeriksaan & \multicolumn{2}{c}{ SGOT dan SGPT } & Jumlah \\
\cline { 2 - 3 } Laboratorium & Meningkat & Menurun & $\%$ \\
\hline BTA $(+)$ & $36 \%$ & $0 \%$ & $91 \%$ \\
BTA (-) & $55 \%$ & $9 \%$ & $9 \%$ \\
Total & $91 \%$ & $9 \%$ & $100 \%$ \\
\hline
\end{tabular}

Tabel 5. Distribusi kadar SGOT dan SGPT berdasarkan Gambaran Radiologi

\begin{tabular}{cccc}
\hline Pemeriksaan & \multicolumn{2}{c}{ SGOT dan SGPT } & Jumlah \\
\cline { 2 - 3 } Faal Hati & Meningkat & Menurun & $\%$ \\
\hline Minimal & $0 \%$ & $0 \%$ & $0 \%$ \\
Moderate & $18 \%$ & $0 \%$ & $18 \%$ \\
Far Advance & $73 \%$ & $9 \%$ & $82 \%$ \\
Total & $91 \%$ & $9 \%$ & $100 \%$ \\
\hline
\end{tabular}

Tabel 6. Distribusi Kadar SGOT dan SGPT berdasarkan OAT KDT

\begin{tabular}{|c|c|c|c|}
\hline \multirow[b]{2}{*}{ OAT KDT } & \multicolumn{2}{|c|}{ SGOT dan SGPT } & \multirow{2}{*}{$\begin{array}{c}\text { Jumlah } \\
\%\end{array}$} \\
\hline & $\begin{array}{l}\text { Mening- } \\
\text { kat }\end{array}$ & $\begin{array}{l}\text { Menu- } \\
\text { run }\end{array}$ & \\
\hline $\begin{array}{l}\text { 2FDC 1x3 + B6 } \\
3 \times 1\end{array}$ & $9,09 \%$ & $0 \%$ & $9,09 \%$ \\
\hline $\begin{array}{l}\text { 2FDC } 1 \mathrm{x} 3+\mathrm{B} 6 \\
1 \mathrm{x} 1\end{array}$ & $18,18 \%$ & $0 \%$ & $18,18 \%$ \\
\hline $\begin{array}{l}\text { 4FDC 1x3 + B6 } \\
1 \mathrm{x} 1\end{array}$ & $18,18 \%$ & $0 \%$ & $18,18 \%$ \\
\hline $\begin{array}{l}2 \text { FDC } 1 \mathrm{x} 4+\mathrm{B} 6 \\
1 \mathrm{x} 1\end{array}$ & $9,09 \%$ & $9,09 \%$ & $18,18 \%$ \\
\hline $\begin{array}{l}\text { Gg 3x1 + B6 3x1 + } \\
\text { Streptomisin 1x1 }\end{array}$ & $9,09 \%$ & $0 \%$ & $9,09 \%$ \\
\hline $\begin{array}{l}\text { R450mg H300mg } \\
\text { Z500mg E500mg }\end{array}$ & $9,09 \%$ & $0 \%$ & $9,09 \%$ \\
\hline $\begin{array}{l}\text { 2FDC 1x3 + B6 } \\
2 \mathrm{x} 1\end{array}$ & $9,09 \%$ & $0 \%$ & $9,09 \%$ \\
\hline $\begin{array}{l}\text { 4FDC 1x3+ } \\
\text { Streptomisin 1x1 + } \\
\text { B6 1x1 }\end{array}$ & $9,09 \%$ & $0 \%$ & $9,09 \%$ \\
\hline Total & $90,9 \%$ & $9,09 \%$ & $99,99 \%$ \\
\hline
\end{tabular}


Tabel 7. Nilai Statistik Deskriptif Pengaruh Pemberian OAT Terhadap Kadar SGOT dan SGPT

\begin{tabular}{lcccc}
\hline Statistik & Pre & Post & Pre & Post \\
Value & SGOT & SGOT & SGPT & SGPT \\
\hline Mean & 26,18 & 42,63 & 21,90 & 29,90 \\
SD & 11,60 & 27,97 & 13,25 & 13,93 \\
Minimum & 15 & 16 & 8 & 13 \\
Maximum & 51 & 114 & 41 & 55 \\
\hline
\end{tabular}

Tabel 8. Hasil Uji Statistik Pengaruh Pemberian OAT Terhadap Kadar SGOT dan SGPT

\begin{tabular}{lcc}
\hline Uji Statistik & Pre-Post SGPT & $\begin{array}{c}\text { Pre-Post } \\
\text { SGOT }\end{array}$ \\
\hline Nilai z & 2,223 & 2,045 \\
Sig. (p) & 0,026 & 0,041 \\
\hline
\end{tabular}

\section{BAHASAN}

Penelitian ini dilakukan untuk mengetahui tentang kadar serum glutamic oxaloacetat transaminase dan serum glutamic pyruvic transaminase pada pasien tuberkulosis paru setelah dua bulan pemberian obat anti tuberkulosis kombinasi dosis tetap.

Sampel pada penelitian ini yaitu pasien dengan diagnosis TB Paru, TB Paru kategori 1, TB paru BTA (+), TB Paru dengan Hipertensi terkontrol, TB paru suspect MDR, TB Paru dengan Infeksi sekunder, TB paru On treatmen, dan TB Paru putus obat di bagian C5 dan Poliklinik Paru di BLU RSUP Prof. Dr.R.D. Kandou Manado.

Pada Tabel 1, didapatkan distribusi berdasarkan jenis kelamin terbanyak adalah jenis kelamin perempuan dengan peningkatan kadar SGOT dan SGPT berjumlah $45 \%$ dan penurunan kadar SGOT dan SGPT berjumlah 10\%. Sejalan dengan penelitian yang dilakukan oleh Ike Pramastuti dkk terhadap 27 pasien didapatkan jumlah pasien laki-laki adalah 11 orang yaitu sebesar 40,74 \% dan perempuan 16 orang yaitu sebesar $59,26 \%$. Peningkatan SGOT pada pasien laki-laki adalah 63,64 \% dan perempuan $81,25 \%$, sedangkan untuk peningkatan SGPT pasien laki-laki adalah $81,82 \%$ dan pasien perempuan $81,25 \%{ }^{6}$

Pada tabel 2, didapatkan distribusi berdasarkan berat badan yang terbanyak adalah kelompok berat badan 56-65 kg dengan peningkatan kadar SGOT dan SGPT berjumlah $46 \%$ dan penurunan kadar SGOT dan SGPT berjumlah $0 \%$.

Pada Tabel 3, didapatkan distribusi berdasarkan Usia yang paling banyak adalah kelompok usia 15-30 tahun dengan peningkatan kadar SGOT dan SGPT berjumlah $46 \%$ dan penurunan kadar SGOT dan SGPT berjumlah 9\%. Sejalan dengan penelitian yang dilakukan ole Ike pramastuti dkk didapatkan bahwa pasien yang menjalani pengobatan Obat Anti Tuberkulosis paling banyak adalah usia 19-29 tahun. $^{6}$

Pada Tabel 4, didapatkan distribusi berdasarkan Pemeriksaan Laboratorium yang terbanyak adalah kelompok BTA (-) dengan peningkatan kadar SGOT dan SGPT berjumlah 55\% dan penurunan kadar SGOT dan SGPT berjumlah 9\%.

Pada Tabel 5, didapatkan distribusi berdasarkan Gambaran radiologi yang terbanyak adalah kelompok Lesi TB Paru Far Advance dengan peningkatan kadar SGOT dan SGPT berjumlah 73\% dan Lesi TB Paru Far Advance dengan penurunan kadar SGOT dan SGPT berjumlah 9\%.

Dari Tabel 6, didapatkan distribusi berdasarkan Obat Anti Tuberkulosis yang terbanyak adalah kelompok 2FDC 1x3 + B6 1x1 dengan peningkatan kadar SGOT dan SGPT berjumlah 18,18\% dan penurunan kadar SGOT dan SGPT berjumlah $0 \%$. Kelompok 4FDC 1x3 + B6 1x1 dengan peningkatan kadar SGOT dan SGPT berjumlah 18,18\% dan penurunan kadar SGOT dan SGPT berjumlah 0\%. Kelompok 2FDC 1x4 + B6 1x1 dengan peningkatan kadar SGOT dan SGPT pada berjumlah 9,09 dan penurunan kadar SGOT dan SGPT berjumlah 9,09\%.

Dari Tabel 7, didpatkan nilai rata-rata (mean) kadar SGOT sebelum pemberian OAT adalah 26,18 dan mengalami peningkatan kadar SGOT setelah pemberian OAT menjadi 42,63. Nilai rata-rata (mean) kadar SGPT sebelum pemberian OAT adalah 21,90 mengalami peningkatan kadar SGPT setelah pemberian OAT menjadi 29,90. Nilai standar deviasi (SD) kadar SGOT sebelum pemberian OAT adalah 11,6 
mengalami peningkatan kadar SGOT setelah pemberian OAT menjadi 27,97. Nilai SD kadar SGPT sebelum pemberian OAT adalah 13,25 mengalami peningkatan kadar SGPT setelah pemberian OAT menjadi 13,93. Nilai minimum kadar SGOT sebelum pemberian OAT adalah 15 mengalami peningkatan kadar SGOT setelah pemberian OAT menjadi 16. Nilai minimum kadar SGPT sebelum pemberian OAT adalah 8 mengalami peningkatan kadar SGPT setelah pemberian OAT menjadi 13. Nilai maximum kadar SGOT sebelum pemberian OAT adalah 51 mengalami peningkatan kadar SGOT setelah pemberian OAT menjadi 114. Nilai maximum kadar SGPT sebelum pemberian OAT adalah 41 mengalami peningkatan kadar SGPT setelah pemberian OAT menjadi 55.

Dari Tabel 8, didapatkan hasil analisis data perubahan kadar SGOT sebelum dan setelah diberikan Obat Anti Tuberkulosis menunjukkan bahwa nilai $\mathrm{z}_{\text {hitung: }}$ 2,223 > $\mathrm{z}_{\text {tabel }}$ : 1,645 dengan nilai signifikansi $\mathrm{p}=$ $0,026<0,05$. Hal ini menunjukkan bahwa terdapat pengaruh pemberian Obat Anti Tuberkulosis (OAT) kadar dosis tetap terhadap kadar SGOT. Hasil analisis data perubahan kadar SGPT sebelum dan setelah diberikan Obat Anti Tuberkulosis menunjukkan bahwa nilai $z_{\text {hitung: 2,045 > }}$ $\mathrm{z}_{\text {tabel }}$ : 1,645 dengan nilai signifikansi $\mathrm{p}=$ $0,041<0,05$. Hal ini menunjukkan bahwa terdapat pengaruh pemberian Obat Anti Tuberkulosis (OAT) kombinasi dosis tetap terhadap kadar SGPT.

Pengobatan TB bertujuan untuk menyembuhkan penyakit, mencegah kematian, mencegah kekambuhan, memutuskan rantai penularan dan mencegah terjadinya resistensi kuman terhadap Obat Anti Tuberkulosis (OAT). Obat lini pertama yang digunakan untuk mengobati TB adalah isoniazid, rifampisin, etambutol, dan pirazinamid untuk terapi awal, dengan streptomisin sebagai terapi alternatif. Isoniazid (INH) dan rifampisin (R) merupakan dua obat yang paling aktif sehingga digunakan sepanjang waktu pengobatan. Penggunaan kombinasi isoniazid dan rifampisin pada pengobatan TB dapat meningkatkan resiko kejadian kerusakan hepar. Adapun insidensi hepatoksisitas lebih tinggi pada penggunaan kombinasi isoniazid dan rifampisin dibandingkan dengan penggunaan isoniazid saja. ${ }^{5}$

\section{SIMPULAN}

Dari hasil penelitian yang dilakukan mengenai kadar serum glutamic oxaloacetate transaminase dan kadar serum glutamic pyruvic transaminase pada pasien tuberkulosis paru selama dua bulan bejalannya pemberian obat anti tuberkulosis konbinasi dosis tetap didapatkan bahwa :

1. Jumlah Penderita TB Paru setelah dua bulan pemberian OAT KDT selama bulan Oktober-Desember 2012 sebanyak 11 Orang.

2. Berdasarkan kelompok umur dengan peningkatan terbanyak umur 15-30 tahun.

3. Berdasarkan jenis kelamin di dapatkan wanita lebih banyak dari pria.

4. Berdasrkan pemeriksaan BTA, kadar SGOT dan SGPT lebih tinggi pada pasien TB paru dengan hasil BTA negatif di bandingkan pasien dengan hasil BTA paru positif.

5. Berdasarkan Gambaran Radiologi pasien TB Paru terbanyak yang memiliki lesi yang sudah meluas (Far Advance).

6. Berdasarkan Obat Anti Tuberkulosis yang terbanyak adalah kelompok 2FDC 1x3 + B6 1x1 dengan peningkatan kadar SGOT dan SGPT berjumlah 18,18\% Kelompok 4FDC 1x3+ B6 1x1 dengan peningkatan SGOT dan SGPT berjumlah $18,18 \%$.

\section{DAFTAR PUSTAKA}

1 Djojodibroto R D. Respirologi (Respirologi medicine). Jakarta. h:151-153. 2009

2 Soehardiman D, Soepandi Z. P dan Nawas M A. Perbandingan Hasil Akhir Pengobatan OAT Kombinasi Dosis Tetap (KDT) dengan KombipaK pada Pengobatan TB Paru dengan Strategi DOTS. Bagian Pulmonologi dan Ilmu Kedokteran Respirasi FKUI, RS Persahabatan - Jakarta

3 Tirtana B.T. Faktor- faktor yang Mempengaruhi Keberhasilan Pengobatan 
Jurnal e-Clinic (eCl), Volume 2, Nomor 3, November 2014

Pada Pasien Tuberkulosis Paru dengan Resistensi Obat Tuberkulosis di Wilayah Jawa Tengah, Semarang. 2012.

4 Julita I. Aspek Farmakokinetik Klinik Beberapa Obat Berpotensi Hepatotoksik Pada Pasien Rawat Inap diBangsal Paru RSUP DR. M. Djamil Padang Periode Oktober 2011- Januari 2012 [Skripsi]. Tersedia dari: https://www.google.com/ search?hl=en\&newwindow $=1 \&$ tbo $=$ d\&biw $=1366 \&$ bih $=643 \& q=$ hepatoksisk + pasien $+T$ $\mathrm{B}+$ paru+dengan $+\mathrm{OAT}+\mathrm{KDT} \&$ oq $=$ hepatoksi sk+pasien+TB+paru+dengan+OAT+KDT\& gs_l=serp.3...29476.55540.0.55826.63.53.10
.0.0.2.346.9522.15j5j31j1.52.0.les\%3B..0.0.. .1c.1.kBGAOVp2T5s

5 Eksa pendim, wahyu siswandari, dan fajar wahyu pribadi, Pengaruh Pemberian Simetidin Terhadap Kadar Sgot dan Sgpt Tikus Putih (rattus norvegicus) Yang diberi Anti Tuberkulosis Rifampisin dan Isoniazid, 2010, Mandala of Health, 4:2. 2010.

6 Pramastuti I, Sutanto YS, Harsini, S AR, Kartodarsono S, Hubungan antara Pemberian Obat Anti Tuberkulosis (OAT) dengan Kadar Enzim Transaminase pada Pasien Tuberkulosis Kasus Baru di RSUD Temanggung. Surakarta. 